\title{
BEHAVIOR OF A CONFINED TENSION LAP SPLICE IN HIGH-STRENGTH REINFORCED CONCRETE BEAMS
}

\author{
Ahmed H. ABDEL-KAREEM ${ }^{1 *}$, Hala ABOUSAFA ${ }^{1}$, Omaia S. EI-HADIDI ${ }^{1}$
}

\begin{abstract}
The results of an experimental program conducted on seventeen simply supported concrete beams to study the effect of transverse reinforcement on the behavior of the lap splice of a steel reinforcement in tension zones in high-strength concrete beams are presented. The parameters included in the experimental program were the concrete compressive strength, the lap splice length, the amount of transverse reinforcement provided within the splice region, and the shape of the transverse reinforcement around the spliced bars. The experimental results showed that the displacement ductility increased and the mode of failure changed from a splitting bond failure to a flexural failure when the amount of the transverse reinforcement in the splice region increased, and the compressive strength increased up to $100 \mathrm{MPa}$. The presence of the transverse reinforcement around the spliced bars had a pronounced effect on increasing the ultimate load, the ultimate deflection, and the displacement ductility. The prediction of maximum steel stresses for spliced bars using the $\mathrm{ACl}$ 318-05 building code was compared with the experimental results. The comparison showed that the effect of the transverse reinforcement around spliced bars has to be considered into the design equations for lap splice length in highstrength concrete beams.
\end{abstract}

\section{Address}

1 Civil Engineering Department, Benha Faculty of Engineering Benha University, Egypt

* Corresponding author: ahmed.abdelkareem@bhit.bu.edu.eg

Key words

- Ductility

- high-strength concrete,

- tension lap splice,

- transverse reinforcement,

- steel stresses.

\section{INTRODUCTION}

An adequate bond between concrete and reinforcing bars in a splice is an essential requirement in the design of reinforced concrete structures. Most design codes specifying the minimum length of the lap splice as well as the required transverse reinforcement. According to ACI 318-05 (2005), a stirrups area in excess of that required for shear and torsion is provided along each terminated bar or wire over a distance (3/4) of the effective depth of a member from the terminal point, without specify a special shape of the stirrups required in the splice zone. Diab (2008) tested twelve normal strength concrete beam specimens. In this study, the type, spacing and shape of the transverse reinforcement in the splice region among other variables were considered. He concluded that there is a drastic increase in the ductility of beams when a transverse reinforcement is used.

Concrete properties have a significant effect on the bond strength between reinforcing bars and concrete. Many researchers have studied the behavior of a tension lap splice in normal strength and high-strength reinforced concrete beams. Azizinamini et al. (1999, 1993) studied the effect of high-strength concrete on a bond using beam splice tests. They noted that the bearing capacity of concrete increased (related to $f_{c}^{\prime}$ ) more rapidly than tensile strength (related to 
$V_{f}$ ) as compressive strength increases. For high-strength concrete, the higher bearing capacity prevents the crushing of the concrete in front of the bar ribs, which reduces local slip. They concluded that, because of the reduced slip, fewer ribs transfer the load between the steel and the concrete, which increases the local tensile stresses and initiates a splitting failure in the concrete prior to achieving a uniform distribution of the bond force. Because of the brittle nature of this failure, they recommended that a minimum quantity of stirrups be used for bars spliced in high-strength concrete.

The main object of the research program reported in this paper is to study the effect of a transverse reinforcement on the strength, mode of failure and displacement ductility of a tension lap splice anchored in high-strength concrete beams with a concrete compressive strength ranging from 60 to $100 \mathrm{MPa}$. To meet the objective, seventeen high-strength concrete beam specimens were tested. Each beam was designed with bars spliced in a constant moment region at the mid-span. The variables used in the investigation were the concrete compressive strength, lap splice length, the amount of the vertical transverse reinforcement to be placed in the splice region, and the shape of the stirrups around the spliced bars. The prediction of the maximum steel stresses in the spliced bars using the ACI Building Code was compared with the experimental results.

\section{EXPERIMENTAL TEST PROGRAM}

\subsection{Test Specimens}

Seventeen reinforced concrete beams were tested in a positive bending. The loading system was designed to produce a constant moment in the middle of the beam specimen. The reinforcement on the tension side consisted of two $16 \mathrm{~mm}$-diameter deformed bars spliced at mid-span. The cross section dimensions of the tested beams were $160 \times 250 \mathrm{~mm}$, and the concrete cover was constant on all sides of the beams and equal to the spliced bar's diameter $\left(d_{b}\right)$.

The length of the beam specimens was $3200 \mathrm{~mm}$ with a distance of $3000 \mathrm{~mm}$ between the supports. The distance between the two applied loads was $1000 \mathrm{~mm}$. The transverse reinforcement was provided outside the splice region of all the beams to avoid shear failure. It consisted of $8 \mathrm{~mm}$ mild steel placed at a spacing of $125 \mathrm{~mm}$. The longitudinal and cross section details of the beam specimens are shown in Fig. 1.

The studies parameters are given in Table 1. and divided into four groups as follows:

\section{Concrete Compressive Strength}

Six beam specimens were tested with a concrete compressive strength ranging from 60 to $100 \mathrm{MPa}$. Three beams did not have any transverse reinforcement in the splice zone, and the other three beams had a transverse reinforcement calculated according to ACI 318-05 for a beam specimen with a concrete compressive strength of $60 \mathrm{MPa}$ (B4).

\section{Length of the Lap Splice (ls )}

Three values of the lap splice length were investigated: $l_{s}=420$, 320 , and $210 \mathrm{~mm}$. The lap splice lengths of 420 and $320 \mathrm{~mm}$ and the required transverse reinforcement in the splice zone were calculated according to ACI 318-05 for the beam specimens with a concrete compressive strength of $60 \mathrm{MPa}$ (B4) and $100 \mathrm{MPa}$ (B7), respectively. The lap splice length of $210 \mathrm{~mm}$ was two-thirds of that required for the beam specimen B7 (B10).

\section{Amount of the Transverse Reinforcement in the Splice Region}

The effect of the amount of the transverse reinforcement crossing the potential splitting plane in the splice region was studied by changing the spacing between the vertical transverse reinforcement. Three different spacing values were studied: $\mathrm{s}=150,125$, and $100 \mathrm{~mm}$.

4. Shapes of the Transverse Reinforcement in the Splice Region

Vertical stirrups with different spacing values were provided in the beam specimens B4 - B12, while vertical stirrups with additional legs were used in beam B13. Beam specimens B14 - B17 included stirrups around the spliced bars with different shapes and spacing plus vertical stirrups at $100 \mathrm{~mm}$ spacing.

The shapes of the stirrups around the spliced bars were rectangular hoops, two interlocking spirals, a continuous spiral around each spliced bar, and continuous rectangular stirrups for beams B14, B15, B16, and B17, respectively, as shown in Fig. 2. All the transverse reinforcement in the splice zone was $6 \mathrm{~mm}$ mild steel.

\subsection{Material Properties}

Three concrete mixtures were used to study the effect of the concrete strength on the splice length. The designed characteristic concrete strengths of the beam specimens were 60,85 , and $100 \mathrm{MPa}$. To produce such a concrete, mineral and chemical admixtures were used plus ordinary Portland cement and fine and coarse aggregates. The fine aggregate was natural sand with a fineness modulus of 2.8 . The coarse aggregate was crushed Dolomite with a maximum size of $10 \mathrm{~mm}$. The mineral admixture was light gray, locally-produced silica fume. The chemical admixture was super-plasticizer, which was used to adjust the workability of the concrete. Typically, three $150 \times 150 \times 150 \mathrm{~mm}$ cubes were cast with each test beam and used for the compression test. A few hours after the casting, the beams and cubes were covered with wet cotton sheets. The form stripping was done two days after the casting; the beams and cubes were maintained under the same curing conditions. A compression test on the cubes was carried out on the same day of the beam testing, and the test results are given in Table 2 .

The yield strength of the bottom longitudinal reinforcement and stirrups used in the lap splice region were 440 and $280 \mathrm{MPa}$ for the diameters of $16 \mathrm{~mm}$ and $6 \mathrm{~mm}$, respectively.

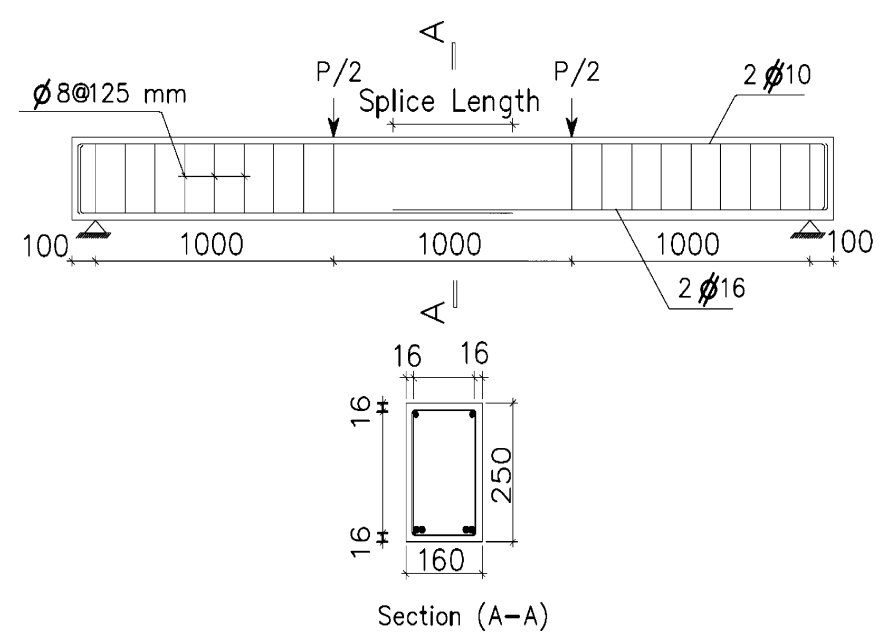

Fig. 1 Longitudinal and cross section details of the beam specimens (Note: all the dimensions are in $\mathrm{mm}$ ). 
Tab. 1 Details of the test specimens.

\begin{tabular}{|c|c|c|c|c|c|}
\hline \multirow{3}{*}{ Beam Specimen } & \multirow{3}{*}{$\begin{array}{c}\text { Concrete } \\
\text { Compressive } \\
\text { Strength (Mpa) }\end{array}$} & \multirow{3}{*}{$\begin{array}{l}\text { Splice Length } \\
(\mathrm{mm})\end{array}$} & \multicolumn{3}{|c|}{ Transverse Reinforcement in Splice Region } \\
\hline & & & \multirow{2}{*}{$\begin{array}{c}\text { Vertical Stirrups } \\
\text { Spacing }(\mathrm{mm})\end{array}$} & \multicolumn{2}{|r|}{ Stirrups around Spliced Bars } \\
\hline & & & & Pitch (mm) & Shape \\
\hline B1 & 60.7 & 420 & - & & None \\
\hline $\mathrm{B} 2$ & 81.2 & 420 & - & & None \\
\hline B3 & 103.2 & 420 & - & & None \\
\hline B4 & 58.7 & 420 & 150 & & None \\
\hline B5 & 80.7 & 420 & 150 & & None \\
\hline B6 & 102.5 & 420 & 150 & & None \\
\hline B7 & 104.3 & 320 & 150 & & None \\
\hline B8 & 99.6 & 320 & 125 & & None \\
\hline B9 & 105.7 & 320 & 100 & & None \\
\hline $\mathrm{B} 10$ & 108.4 & 210 & 150 & & None \\
\hline B11 & 101.6 & 210 & 125 & & None \\
\hline $\mathrm{B} 12$ & 104.3 & 210 & 100 & & None \\
\hline B13 & 102.6 & 210 & 100 & & Vertical stirrups with the addition of legs \\
\hline B14 & 103.7 & 210 & 100 & 100 & Rectangular stirrups \\
\hline B15 & 105.8 & 210 & 100 & 60 & Two interlocking spirals \\
\hline B16 & 106.7 & 210 & 100 & 60 & Continuous spiral around each spliced bar \\
\hline $\mathrm{B} 17$ & 104.5 & 210 & 100 & 60 & Continuous rectangular stirrups \\
\hline
\end{tabular}

\subsection{Test Setup and Test Procedure}

The load was applied through a mechanical screw jack and was transferred to the test beam through a steel spreader beam that was supported on two steel rollers covering the entire width of the beam. The load was measured using an electrical load cell under the screw jack with a maximum capacity of $1000 \mathrm{KN}$. The deflections were measured by three Linear Variable Displacement Transducers (LVDTs). Two LVDTs were placed under the two load points, and the third one was placed under the middle of the beam span. The Load cell and three LVDTs were connected to a data acquisition system to record the data. Figs. 3 and 4 show the schematic and a photograph of the test setup for a splice beam.

The load was applied to the specimens until cracking was observed on the tension side of the beams. While the load was held constant, the cracks were traced. Loading continued in this fashion, with pauses after approximately $5 \mathrm{KN}$ increments for tracing the cracks. The loading was continuous after failure using the screw jack. The output data were recorded by the data acquisition system. Pictures were taken after the failure, and the spalled concrete was used to measure the actual cover.
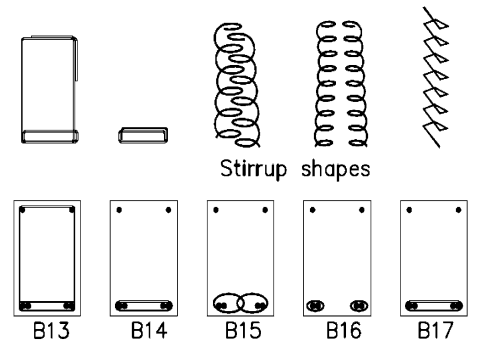

Cross - Sections

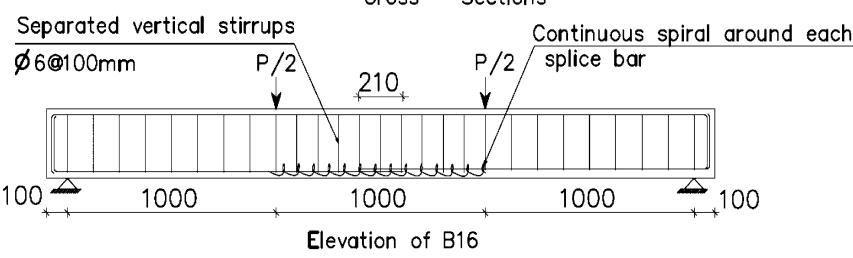

Fig. 2 Details of stirrups around the spliced bars.
Tab. 2 Details of the concrete mixes.

\begin{tabular}{|c|c|c|c|c|c|c|}
\hline \multirow{2}{*}{$\begin{array}{c}\text { Target } \\
f_{c} \\
(\mathrm{Mpa}) \\
\end{array}$} & \multicolumn{5}{|c|}{$\operatorname{Mix} \operatorname{Proportion}\left(\mathrm{KN} / \mathrm{m}^{3}\right)$} & \multirow{2}{*}{$\begin{array}{c}\text { Dosage of } \\
\text { Super- plasti- } \\
\text { cizer }\end{array}$} \\
\hline & Dolomite & Sand & Water & Cement & $\begin{array}{l}\text { Silica } \\
\text { Fume }\end{array}$ & \\
\hline 100 & 12.500 & 5.00 & 1.430 & 467 & 0.825 & 3.0 \\
\hline 85 & 12.500 & 5.00 & 1.650 & 4.950 & 0.550 & 2.0 \\
\hline 60 & 11.600 & 5.80 & 1.800 & 4.500 & - & 1.0 \\
\hline
\end{tabular}

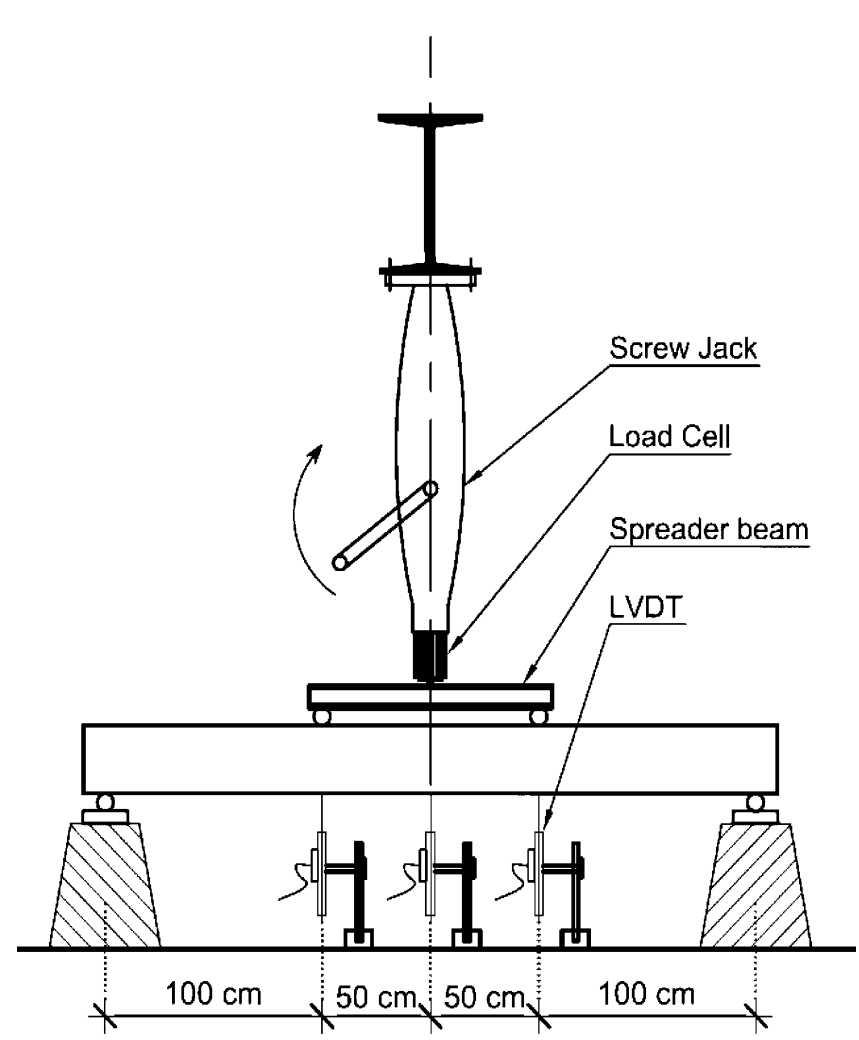

Fig. 3 Schematic of the test set-up for a splice beam. 


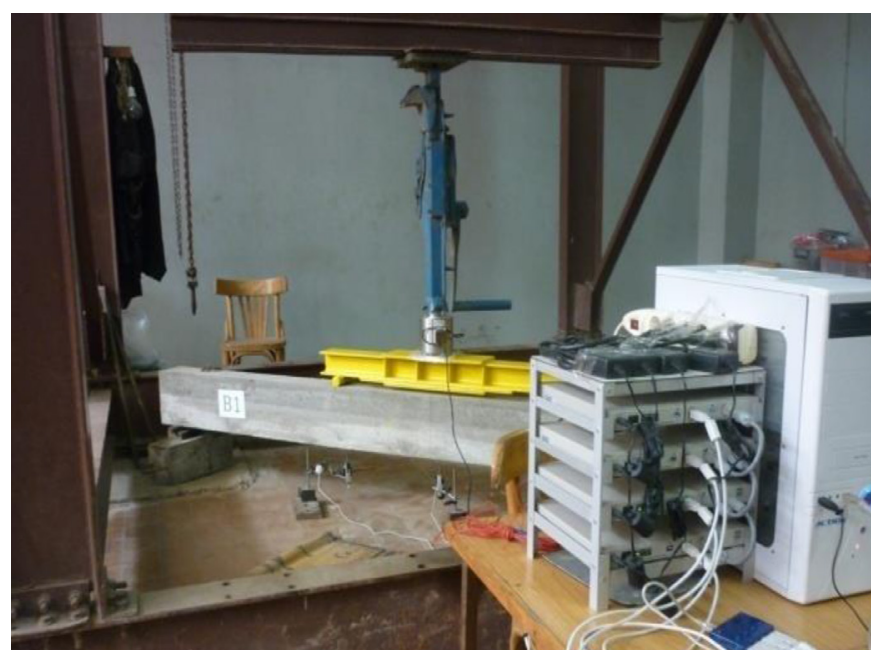

Fig. 4 Splice beam prior to the testing.

\section{EXPERIMENTAL RESULTS AND DISCUSSION}

A brief summary of the test results is given in Table 3 . The test results will be discussed in the following items:

\subsection{Failure Mode}

The first flexural cracks in all the beams occurred randomly in the constant moment region on the tension side of the beam outside the splice length; as the load increased, cracks formed along the entire length of the constant moment region, including the splice region. The failure modes of the tested specimens were either a splitting bond failure or ductile flexural failure according to the confinement provided by the transverse reinforcement. The beam specimens without a confining transverse reinforcement along the splice length failed suddenly after the initiation of the splitting cracks without any warning or propagation of the cracks accompanied by the loss of the concrete cover over the entire lap splice length as shown in Fig. 5.

The splitting failure of the beam specimens with the transverse reinforcement in the splice region was more ductile and allowed for the propagation of the splitting cracks between the flexural cracks prior to failure. The presence of the transverse reinforcement eliminated the propagation and widening of the splitting cracks. The splitting failure for the beam specimens with a lap splice length of less than that required by the ACI code did not show any ductility, and the load dropped suddenly after reaching a peak. Fig. 6 shows the typical splitting failure of the beam specimens with a transverse reinforcement in the splice region.

For the flexural failure, the flexural cracks extended upward and were very close to the top surface of the beam; very narrow longitudinal splitting cracks occurred along the splices, without a splitting failure. The ductile flexural failure took place by crushing of the concrete in compression nearly the concentrated load. Fig. 7 shows the typical flexural failure of the beam specimens. A summary of the mode of failure for the tested beams is shown in Table 3 .

Comparing the mode of failure of the beam specimens, the failure mode changed from a splitting bond failure to a ductile flexural failure in these cases:

1) Increasing the concrete compressive strength up to $100 \mathrm{Mpa}$ for the beam specimen included a transverse reinforcement in the splice region (B6).

2) Increasing the vertical transverse reinforcement in the splice region more than $25 \%$ than that required by the $\mathrm{ACI}$ code $(\mathrm{B} 8, \mathrm{~B} 9)$.
3) Using stirrups around the spliced bars in the beam specimens with a lap splice length two-thirds of that required by the ACI code (B13-B17), while the beam specimen with the same splice length and vertical stirrups suddenly failed.

\subsection{Load-Deflection Behavior}

The relationship between the load and mid-span deflection for the beam specimens is presented in Figs. 8-11. The flexural stiffness of all the tested beams was almost identical below the cracking load. Fig. 8 shows that after cracking, the stiffness of the tested beams increased (less deflection for the same load) as the concrete compressive strength increased. The post-cracking stiffness was almost identical for all the beam specimens with the same concrete compressive strength, and were not affected by the presence, amount or shape of the transverse reinforcement. There was a consistent increase in the ultimate load and the deflection as the concrete compressive strength, lap splice length, and the amount of transverse reinforcement in the splice region increased. By providing stirrups around the spliced bars, the beam specimens were capable of carrying more of a load, and the deflection significantly increased, especially for the beams with two interlocking spirals around the spliced bars, B15, and a continuous spiral around

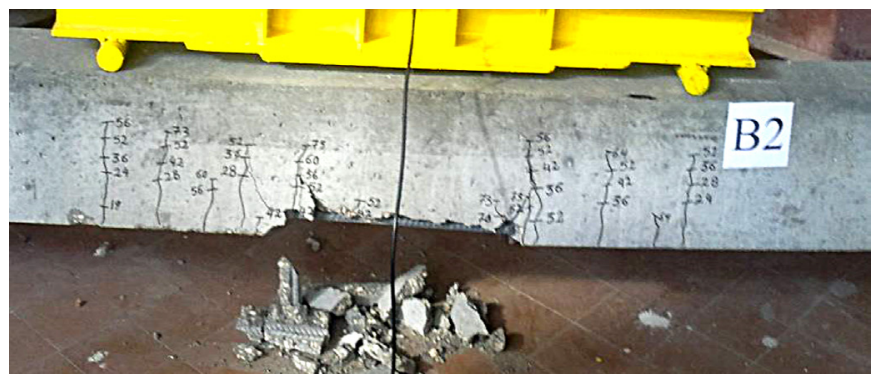

Fig. 5 Typical splitting failure for beam specimens without a confining transverse reinforcement.

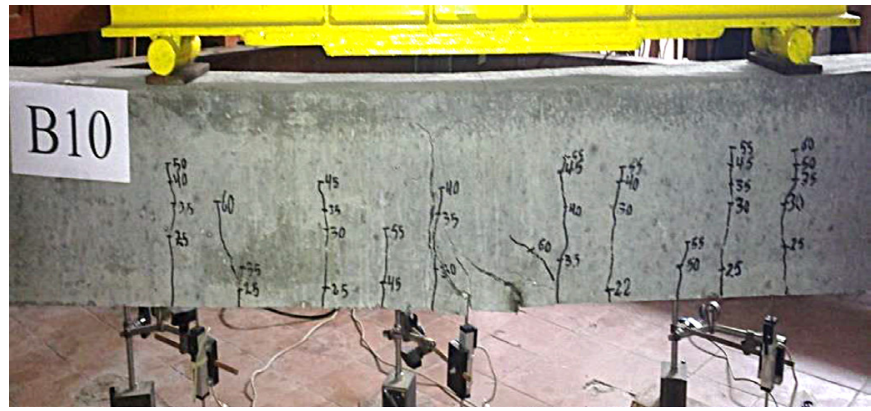

Fig. 6 Typical splitting failure for beam specimens with a confining transverse reinforcement in splice region.

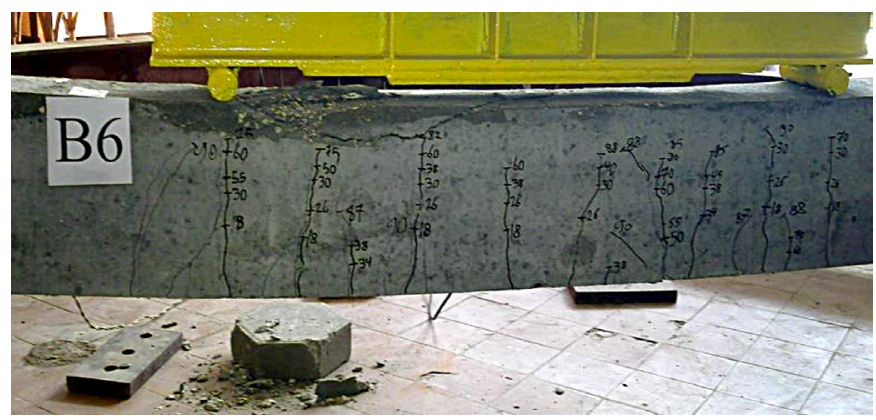

Fig. 7 Typical flexure failure for the beam specimens. 


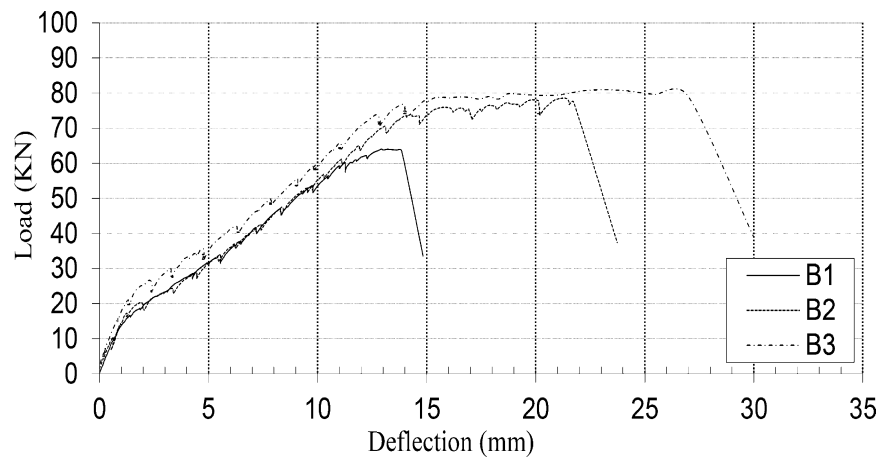

(a) Without stirrups

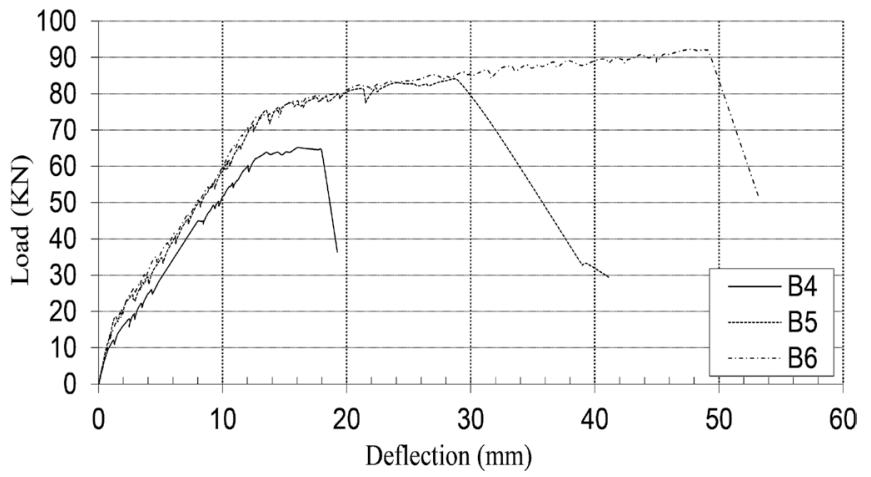

(b) With vertical stirrups

Fig. 8 Load-deflection curves for the beam specimens with different concrete compressive strength.

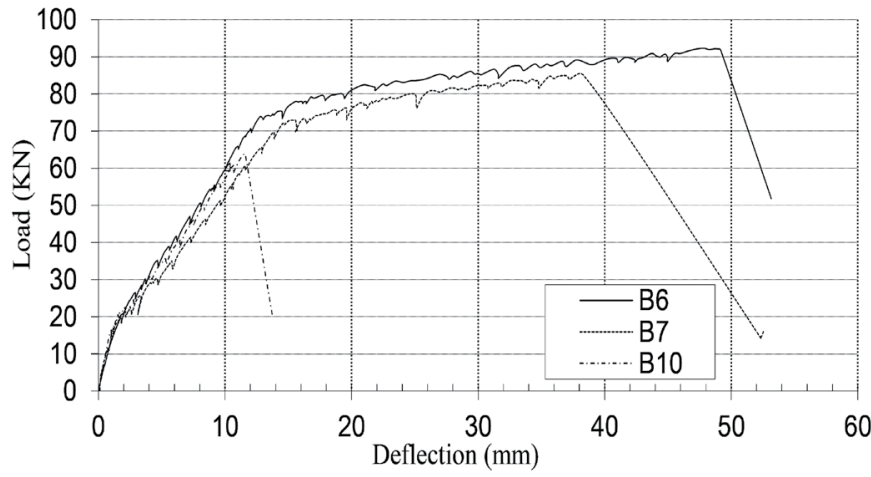

Fig. 9 Load-deflection curves for the beam specimens with different lap splice lengths (Vertical stirrups at $150 \mathrm{~mm}$ spacing in the splice region).

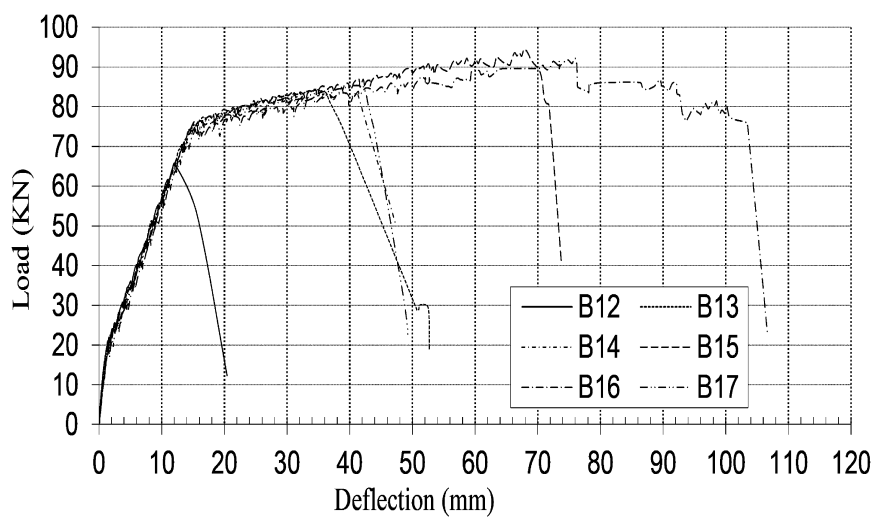

Fig. 11 Load-deflection curves for beam specimens with different shapes of stirrups in the splice region.

each spliced bar, B16. Comparing with beam specimen with vertical transverse reinforcement only in the splice region, B12, the ultimate load for B15 and B16 increased by $45 \%$ and $41 \%$, respectively, and the ultimate deflection for B15 and B16 increased by $366 \%$ and $493 \%$, respectively.

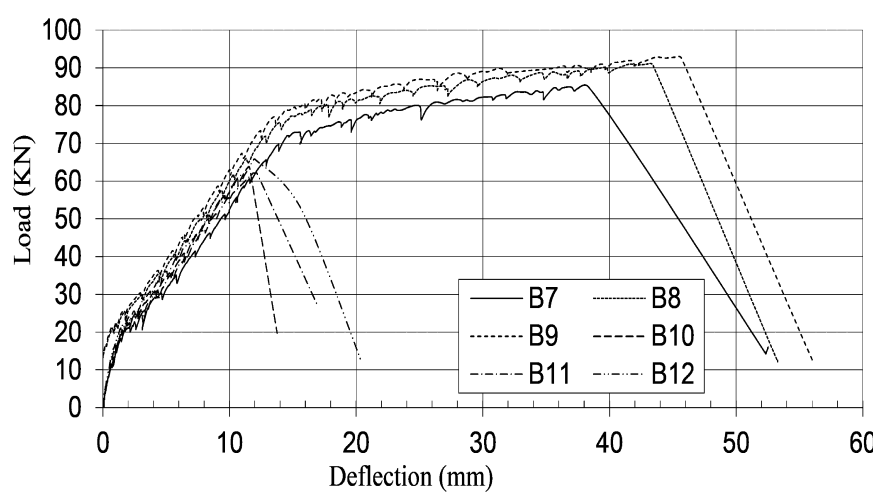

Fig. 10 Load-deflection curves for the beam specimens with different vertical stirrup spacing in the splice region.

\subsection{Displacement Ductility}

The displacement ductility ratio $(\mu)$, as seen in Fig. 12, is defined as the ratio of the maximum deflection (the deflection when the load decreased to $80 \%$ of the ultimate value along the descending branch of the load deflection curve) and the deflection at the point of yield of the reinforcement steel. The displacement ductility for the tested beams is shown in Table 3 .

As indicated by the comparison of the test results of the beam specimens with different concrete compressive strength, the displacement ductility increased as the concrete compressive strength increased, and this increase was more rapid with the presence of the transverse reinforcement in the splice region. The displacement ductility drastically decreased when the lap splice length decreased to two-thirds of that required by the ACI code. A comparison of the beam specimens with variable spacing between the vertical transverse reinforcement in the splice region indicated that the displacement ductility increased by increasing the amount of the vertical transverse reinforcement crossing the potential splitting plane in the splice region. The greatest increase in the displacement ductility was when the stirrups around the spliced bars were used in the splice region, especially in a continuous spiral around each spliced bar, B16, and two interlocking spirals around the spliced bars, B15. 
Tab. 3 Summary of test results.

\begin{tabular}{ccccccccc}
\hline $\begin{array}{c}\text { Beam } \\
\text { Specimen }\end{array}$ & $\begin{array}{c}\text { Concrete } \\
\text { Compressive } \\
\text { Strength (Mpa) }\end{array}$ & $\begin{array}{c}\text { Ultimate } \\
\text { Load } \\
\mathrm{Pu}(\mathrm{KN})\end{array}$ & $\begin{array}{c}\text { Deflection at } \\
\text { Yield Load } \\
\Delta \mathrm{y}(\mathrm{mm})\end{array}$ & $\begin{array}{c}\text { Deflection at } \\
\text { Pu } \\
\Delta \mathrm{u}(\mathrm{mm})\end{array}$ & $\begin{array}{c}\text { Deflection at } \\
80 \% \text { Pu } \\
\Delta \max (\mathrm{mm})\end{array}$ & $\begin{array}{c}\text { Mode } \\
\text { of Failure }\end{array}$ & $\begin{array}{c}\text { Displacement } \\
\text { Ductility } \\
(\mu)\end{array}$ & $\begin{array}{c}\text { Stresses in } \\
\text { Spliced Bars at } \\
\text { Failuref }(\mathrm{Mpa})\end{array}$ \\
\hline B1 & 60.7 & 64.0 & 12.10 & 12.92 & 14.20 & Splitting & 1.17 & 375.65 \\
B2 & 81.2 & 78.5 & 14.00 & 21.73 & 22.50 & Splitting & 1.61 & 460.35 \\
B3 & 103.2 & 80.8 & 14.00 & 18.29 & 28.00 & Splitting & 2.00 & 467.77 \\
B4 & 58.7 & 65.1 & 12.70 & 13.40 & 18.50 & Splitting & 1.46 & 383.75 \\
B5 & 80.7 & 83.6 & 14.00 & 28.14 & 32.80 & Splitting & 2.34 & 492.74 \\
B6 & 102.5 & 92.3 & 14.50 & 47.77 & 50.40 & Flexure & 3.48 & 538.68 \\
B7 & 104.3 & 85.1 & 15.40 & 38.32 & 42.00 & Splitting & 2.73 & 493.68 \\
B8 & 99.6 & 90.9 & 14.00 & 41.57 & 45.95 & Flexure & 3.28 & 531.35 \\
B9 & 105.7 & 92.8 & 14.50 & 43.71 & 48.20 & Flexure & 3.32 & 541.16 \\
B10 & 108.4 & 63.9 & 11.50 & 11.50 & 12.20 & Splitting & 1.06 \\
B11 & 101.6 & 62.2 & 12.05 & 10.63 & 14.00 & Splitting & 1.16 & 369.78 \\
B12 & 104.3 & 65.7 & 12.04 & 12.04 & 15.80 & Splitting & 1.31 & 360.22 \\
B13 & 102.6 & 84.3 & 14.90 & 34.39 & 41.00 & Flexure & 2.75 & 380.66 \\
B14 & 103.7 & 83.7 & 15.00 & 38.68 & 44.50 & Flexure & 2.97 & 489.30 \\
B15 & 105.8 & 94.3 & 15.00 & 55.76 & 72.00 & Flexure & 4.80 & 485.32 \\
B16 & 106.7 & 92.7 & 16.00 & 56.53 & 103.50 & Flexure & 6.47 & 550.24 \\
B17 & 104.5 & 85.3 & 15.20 & 40.67 & 44.70 & Flexure & 2.94 & 539.60 \\
\hline
\end{tabular}

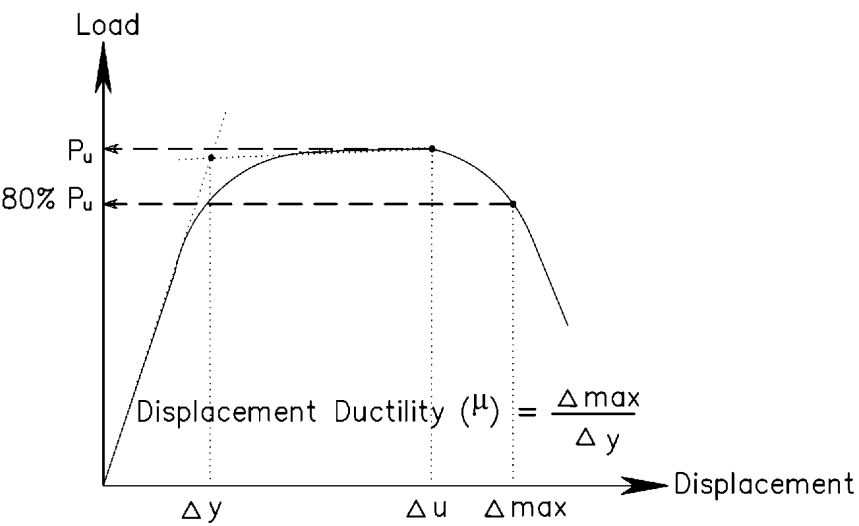

Fig. 12 Definition of displacement ductility.

\subsection{Stresses in the Sliced Bars}

The average stresses in the spliced bars at the ultimate load $\mathrm{P}_{\mathrm{u}}$ were calculated using the rectangular stress block for concrete given in ACI 318-05 with the safety factors taken as 1.0 . The reinforcement stresses were obtained from the maximum applied moment for the concrete strengths used in this investigation. A quadratic expression was used to determine the tensile force in the longitudinal reinforcement, which was divided by the total area of the reinforcement at a section outside the splice zone to obtain the average reinforcement stresses at the ultimate load. Table 3. shows the stresses in the spliced bars for the beam specimens.

\section{COMPARISON WITH ACI 318-05}

The stresses in the spliced bars from the experimental program were compared to those calculated using the ACI 318-05 design provisions. The development length $l_{d}$ in the ACI code was replaced by $l s / 1.3$ to account for the bar casting position, which is given as follows:

$$
\begin{aligned}
& \frac{l_{d}}{d_{b}}=\frac{9}{10} \frac{f_{v}}{\sqrt{f_{c}^{\prime}}} \frac{\lambda}{\frac{c+k_{t r}}{d_{b}}} \\
& \frac{\left(c+K_{t r}\right)}{d_{b}} \leq 2.5 ; K_{t r}=\frac{A_{t r} f_{v t}}{10 s n}
\end{aligned}
$$

where,

$f_{y}=$ yield strength of the reinforcement steel which could be replaced by $f_{s}$ to evaluate the stress in the reinforcing bar for a given splice length, $l s, \mathrm{MPa}$;

$f_{y t}=$ yield strength of the transverse reinforcement, $\mathrm{MPa}$;

$f_{c}^{\prime}=$ cylinder compressive strength of the concrete, MPa;

$\gamma=$ reinforcement size factor $(=0.8$ For No. 6 (19 $\mathrm{mm}$ diameter $)$ and smaller);

$c=$ spacing or cover diameter, $\mathrm{mm}$;

$K_{t r}=$ transverse reinforcement index;

$A_{t r}=$ total cross-section area of all the transverse reinforcements that are within the spacing $s, \mathrm{~mm}^{2}$;

$n=$ number of bars being spliced or developed along the plane of splitting;

$s=$ center-to-center spacing of the transverse reinforcement within the splice length, $\mathrm{mm}$.

The predicted steel stresses for the beam specimens is shown in Table 4. This table also provides the ratios of the experimental stresses to the predicted stresses according to the code equation. For the beam specimens beams with stirrups around the spliced bars are excluded; the average of the ratios of the experimental / predicted stresses is 1.06 with a standard deviation of 0.12 . The ACI code underestimates the steel stresses when stirrups are added around the spliced bars in the beam specimens; for those beams the average of the ratios of the experimental / predicted stresses is 1.61 with a standard deviation of 0.09 . This result can be attributed to the high stresses in the reinforcing bars. These high stresses induced high bearing forces on the concrete in the surrounding area of the ribs, which can be translated into 
two components: the horizontal component, which causes the bond forces with the concrete, and the vertical component, which causes the splitting forces. These splitting forces are resisted by the vertical transverse reinforcement and stirrups around the spliced bars. The contribution of the confining stirrups around the tension lap splices in high-strength concrete in resisting the splitting force has to be evaluated in a further experimental study that takes into consideration the different variables.

Tab. 4 Comparison between the experimental and predicted stresses in the spliced bars.

\begin{tabular}{cccc}
\hline $\begin{array}{c}\text { Beam } \\
\text { Specimen }\end{array}$ & $\begin{array}{c}\text { Experimental } \\
\text { Stresses (Mpa) }\end{array}$ & $\begin{array}{c}\text { Predicted } \\
\text { Stresses } \\
\text { (Mpa) }\end{array}$ & $\begin{array}{c}\text { Experimental / Predicted } \\
\text { Steel Stresses }\end{array}$ \\
\hline B1 & 375.65 & 376.04 & 1.00 \\
B2 & 460.35 & 434.92 & 1.06 \\
B3 & 467.77 & 490.31 & 0.95 \\
B4 & 383.75 & 441.38 & 0.87 \\
B5 & 492.74 & 517.65 & 0.95 \\
B6 & 538.68 & 583.25 & 0.92 \\
B7 & 493.68 & 448.27 & 1.10 \\
B8 & 531.35 & 452.26 & 1.17 \\
B9 & 541.16 & 487.86 & 1.11 \\
B10 & 369.78 & 299.90 & 1.23 \\
B11 & 360.22 & 299.76 & 1.20 \\
B12 & 380.66 & 318.03 & 1.20 \\
\hline \multicolumn{5}{c}{ mean } & 1.06 \\
B13 & standard deviation & 0.12 \\
B14 & 489.30 & 315.43 & 1.55 \\
B15 & 485.32 & 317.12 & 1.53 \\
B16 & 550.24 & 320.31 & 1.72 \\
B17 & 539.60 & 321.67 & 1.68 \\
\hline \multicolumn{5}{c}{494.85} & 318.34 & 1.55 \\
\hline \multirow{5}{*}{ According to ACI 318-05 } & 1.61 \\
\hline & mean & 0.09 \\
\hline \multicolumn{3}{c}{ standard deviation } & \\
\hline
\end{tabular}

\section{CONCLUSIONS}

Seventeen high-strength concrete beams containing an overlapping splice of two bars under a constant bending moment were experimentally studied. Based on the analysis and comparison of the mode of failure, the ultimate load, the load-deflection behavior, the displacement ductility and the steel stresses in the spliced bars, the following conclusions were made:

1) The failure of the beam without a transverse reinforcement was suden and violent and occurred along the entire length of the splices.

2) For the splices confined by a transverse reinforcement, by increasing the concrete compressive strength, the mode of failure was more ductile, and the final mode of failure changed to a flexural failure for a beam specimen with a compressive strength of $100 \mathrm{MPa}$.

3) As the amount of the transverse reinforcement in the splice region increased, the mode of failure became more ductile. For a $25 \%$ increase in the transverse reinforcement than that required by ACI 318-05, the failure mode changed to a flexural failure.

4) Whatever the amount of transverse reinforcement in the splice zone, by decreasing the lap splice length to two-thirds of that required by ACI 318-05, the ultimate load capacity significant- ly decreased, and the mode of failure was a splitting failure without any ductility.

5) By providing stirrups around the spliced bars in the beam specimens with a lap splice length two-thirds of that required by ACI 318-05, the ultimate load capacity increased; the mode of failure changed to flexural ductility; and the displacement ductility drastically increased, especially by using spiral stirrups either interlocking around the spliced bars or continuously around each spliced bar.

6) The stiffness of the beams with the same compressive strength (resistant to deflection) was identical below and above the flexural cracking load, whatever the lap splice length and the amount of transverse reinforcement in the splice region.

7) The steel stresses in the spliced bars were well predicted by ACI 318-05 for all the beam specimens without stirrups around the spliced bars. For these beams, the average experimental/ predicted steel stress was 1.06 with a standard deviation of 0.12 . ACI $318-05$ provided an underestimate of the steel stresses in the beam specimens with a transverse reinforcement around the spliced bars. For these beams, the average experimental /predicted steel stress was 1.61 with a standard deviation of 0.09 .

8) It is recommended to confine the tension lap splice in highstrength concrete by spiral stirrups around the spliced bars, especially shorter splices than that required by the code provisions. This confinement will provide ductility to the mode of failure and will significantly improve the load capacity.

9) It is desirable that further work propose a factor that reflects the contribution of confining a transverse reinforcement around spliced bars in the design equations for tension lap splice length. 


\section{REFERENCES}

ACI 318-05 (2005) Building Code Requirements for Structural Concrete and Commentary, American Concrete Institute, Farmington Hills, Mich.

ACI Committee 408 (2003) Bond and Development of Straight Reinforcing Bars in Tension, ACI 408R-03, American Concrete Institute, Farmington Hills, Mich.

Azizinamini, A. - Chisala, M. - Roller, J. H.- Ghosh, S. K. (1995) Tension Development Length of Reinforcing Bars Embedded in High-Strength Concrete, Engineering Structures, V. 17, No. 7, 1995, pp. 512-522.

Azizinamini, A. - Darwin, D. - Eligehausen, R. - Pavel, P. - Ghosh, S. K. (1999) Proposed Modifications to ACI 318-95 Tension Development and Lap Splice for High-Strength Concrete, ACI Structural Journal, V. 96, No. 6, Nov.-Dec. 1999, pp. 922-926.

Azizinamini, A. - Stark, M.- Roller, J. H. - Ghosh, S. K. (1993) Bond Performance of Reinforcing Bars Embedded in HighStrength Concrete, ACI Structural Journal, V. 90, No. 5, Sept.Oct. 1993, pp. 554-561.

Diab, A. M. (2008) Lap Splices in Reinforced Concrete Beams Subjected to Bending, Master thesis, University of Alexandria, Egypt.
Esfahani, M. R. - Rangan, B.V. (1998) Bond between Normal Strength and High-Strength Concrete (HSC) and Reinforcing Bars in Splices in Beams, ACI Structural Journal, V. 95, No. 3, May-June 1998, pp. 272-280.

Hamad, B. S. - Najjar, S. (2002) Evaluation of the Role of Transverse Reinforcement in Confining Tension Lap Splices in High Strength Concrete, Materials and Structures, V. 35, May 2002, pp. 219-228.

Park, R. - Ruitong, D. (1998) Ductility of Doubly Reinforced Concrete Beam Sections, ACI Structural Journal, V. 85, No. 3, Mar.Apr. 1998, pp. 217-225.

Turk, K. - Yildirim, M. S. (2002) Bond Strength of Reinforcement in Splices in Beams, Structural Engineering and Mechanics, V. 16, No. 4.

Zuo, J. - Dawin, D. (2000) Splice Strength of Conventional and High Relative Rib Area Bars in Normal and High-Strength Concrete, ACI Structural Journal, V. 97, No. 4, July-Aug. 2000, pp. 630-641. 